\title{
Long-Term Repopulating Ability of Xenogeneic Transplanted Human Fetal Liver Hematopoietic Stem Cells in Sheep
}

\author{
Esmail D. Zanjani, * Alan W. Flake, ${ }^{\star}$ Henry Rice, ${ }^{\star}$ Mark Hedrick, ${ }^{\star}$ and Mehdi Tavassoli ${ }^{\mathbf{t}}$ \\ * Department of Medicine, Department of Veterans Affairs Medical Center, University of Nevada School of Medicine, Reno, Nevada \\ 89520; ${ }^{\ddagger}$ University of California School of Medicine, San Francisco, California 94143; and ${ }^{\S}$ Department of Veterans Affairs Medical \\ Center, University of Mississippi School of Medicine, Jackson, Mississippi 39216
}

\begin{abstract}
We previously reported on the successful engraftment and long-term multilineage expression (erythroid, myeloid, lymphoid) of human fetal liver hematopoietic stem cells in sheep after transplantation in utero. That the engraftment of longterm repopulating pluripotent stem cells occurred in these animals was shown here by the fact that transplantation of human $\mathrm{CD}^{+}{ }^{+}$cells isolated from bone marrow of these chimeric animals into preimmune fetal sheep resulted in engraftment and expression of human cells. Marrow cells were obtained from three chimeric sheep at 3.2-3.6 yr after transplant. The relative percentage of human $\mathrm{CD}^{+} 5^{+}$cells present in these marrows was $3.3 \pm 0.32 \%$. A total of $29 \times 10^{6} \mathrm{CD}^{+} 5^{+}$cells were isolated by panning, pooled, and transplanted into six preimmune sheep fetuses $\left(4.8 \times 10^{6}\right.$ cells $/$ fetus $)$. All six recipients were born alive. Hematopoietic progenitors exhibiting human karyotype were detected in marrows of two lambs soon after birth. Cells expressing human CD45 antigen were also detected in blood and marrow of both lambs. Human cell expression has been multilineage and has persisted for $>1$ yr. These results demonstrate that the expression of human cells in this large animal model resulted from engraftment of long-term repopulating pluripotent human stem cells. (J. Clin. Invest. 1994. 93:10511055.) Key words: hematopoietic stem cells • human/sheep xenograft $\bullet$ in utero transplantation $\bullet$ preimmune fetus $\bullet$ fetal liver
\end{abstract}

\section{Introduction}

Human hematopoiesis is maintained throughout life by a unique population of progenitor cells known as the hematopoietic stem cells (HSC). ${ }^{1}$ The two major characteristics that define HSC are their capability for multilineage differentiation that results in the production of the various blood cell lineages and their capacity to give rise to progeny cells with functional characteristics similar to their own (1-3). The latter, a process

\footnotetext{
${ }^{\dagger}$ Deceased.

Address correspondence to Esmail D. Zanjani, Ph.D., Veterans Affairs Medical Center (151B), 1000 Locust Street, Reno, NV 89511.

This work was presented in part at the American Society of Hematology annual meeting in Anaheim, CA on 3-7 December 1992.

Received for publication 8 September 1993 and in revised form 2 November 1993.
}

1. Abbreviations used in this paper: BFU-E, erythroid burst-forming unit; BMNC, light density bone marrow mononuclear cells; CFU-GM, granulocyte macrophage CFU; CFU-Mix, multipotent CFU; HSC, hematopoietic stem cells.

The Journal of Clinical Investigation, Inc.

Volume 93, March 1994, 1051-1055 known as self-renewal, is the pivotal function that insures HSC survival (4). It is these two biological properties that make HSC the cellular element believed to be responsible for the reestablishment of hematopoiesis after bone marrow transplantation.

The existence of HSC and its long-term repopulating ability have been well established in animals and humans (5-10). In mice, the use of lethally irradiated recipients as an in vivo assay has permitted the study of not only the repopulating ability of HSC but also its self-renewal capacity. In conjunction with in vitro assay systems, the irradiated mouse assay has been the critical element in the isolation and phenotypic and functional characterization of mouse HSC (11). In this connection, functional cell studies have led to the recognition of at least two populations of HSC with regard to their ability to repopulate hematopoietic tissues in mice; short-term populating cells can repopulate hematopoietic tissues much faster, but their populating ability does not last long. The other HSC type can repopulate hematopoietic tissue on a long-term basis (12-15).

A great deal of progress has also been made in the identification and characterization of human HSC (8-10, 16-18). Progress in the phenotypic identification of human $\operatorname{HSC}(8,9$, $19)$, its isolation in relatively pure form $(8,9,20)$, its extensive characterization in vitro (17, 21-24), and the study of its behavior in selected animal models have made it possible to experimentally approach the study of one or more functions of human HSC in vivo $(10,18,25-28)$. In this regard, the successful engraftment and expression of human stem cells in immunodeficient mice provided an excellent model to study long-term human hematopoiesis in vivo $(10,18,25,26)$. More recently, we described the engraftment and long-term expression of human HSC in sheep after transplantation in utero (27). In this large animal model, the permissive environment of the early gestational age fetus, characterized by its immunological naiveté and the availability of sites for homing/engraftment of donor HSC, permits the engraftment of human HSC without the need for cytoablative procedures $(27,28)$.

We previously reported the successful engraftment and expression of human fetal liver (27) and adult (28) bone marrow HSC in this model. The engraftment, now $>4 \mathrm{yr}$ after transplant, has been long-term and associated with multilineage expression involving donor (human) erythroid, lymphoid, and myeloid cells (27). To determine whether donor cell activity in these chimeric lambs resulted from the engraftment of longterm repopulating human $\mathrm{HSC}$, we transplanted human $\mathrm{CD}_{4} 5^{+}$cells obtained from bone marrow of three human/ sheep chimeric animals at 3.2-3.6 yr after transplant into six normal preimmune sheep fetuses. We report here the presence of donor (human ) cells and hematopoietic progenitors in bone marrow and blood of two of these secondary recipients. Multilineage donor cells / progenitors engraftment were first detected at 3 wk after birth (i.e., 4 mo after transplant) and have per- 
Table I. Human Cell Expression in Donor Human/Sheep Chimeric Lambs*

\begin{tabular}{cccc}
\hline & \multicolumn{3}{c}{ Animal } \\
\cline { 2 - 4 } Donor human cells & 3419 & 3425 & $3425 \mathrm{C}$ \\
\hline & $\%$ & $\%$ & $\%$ \\
$\mathrm{CD} 5^{+}$ & 3.1 & 2.6 & 3.2 \\
$\mathrm{CD}^{+}$ & 0.3 & 0.6 & 0.4 \\
$\mathrm{CD} 4^{+}$ & 0.8 & 0 & 1.1 \\
$\mathrm{CD} 22^{+}$ & 0.6 & 1.1 & 1.6 \\
$\mathrm{CD} 14^{+}$ & 2.1 & 1.7 & $\pm^{\ddagger}$ \\
\end{tabular}

* All values were determined on BMNC obtained 2 wk before these studies. Relative distributions of donor (human) hematopoietic progenitors (determined by karyotyping of progenitor-derived colonies) were: Lamb 3419: CFU-Mix 2.4\%, CFU-GM 5.2\%, BFU-E 1.2\%; Lamb 3425: CFU-Mix 1.8\%, CFU-GM 7.4\%, BFU-E 0\%; and Lamb 3425C: CFU-Mix 3.6\%, CFU-GM 6.9\%, BFU-E 3.8\%.

₹ery low levels $(<0.1 \%)$ detected.

sisted for $>1 \mathrm{yr}$. These results demonstrate that the expression of human cells in the human/sheep xenograft model resulted from the engraftment and in vivo self-renewal of long-term repopulating human HSC. Our findings also indicate the suitability of this large animal model for the study of the engraftment and long-term repopulating potentials of human HSC populations.

\section{Methods}

Donor cell preparation and transplantation procedures. Human $\mathrm{CD}^{+} 5^{+}$cells were isolated by panning light density bone marrow mononuclear cells (BMNC) obtained from three separate donor chimeric sheep at 3.2, 3.4, and $3.6 \mathrm{yr}$ after in utero transplantation with human fetal liver HSC. The creation of these chimeric sheep has been described in detail previously (27). Briefly, preimmune fetal lambs at 48-54 d gestation (term: $145 \mathrm{~d}$ ) were transplanted with hematopoietic cells $\left(2 \times 10^{9}-1 \times 10^{10}\right.$ cells $/ \mathrm{kg}$ estimated fetal body wt $)$ derived from livers of 12-15-wk-old human fetuses. This resulted in the creation of stable, multilineage human hematopoietic chimerism in a number of the recipients (27). Full characterization of some of these chimeric animals including the three donors (3419, 3425, and 3425C) used here have been published elsewhere (27). At the time of these studies, all three sheep continued to express human hematopoietic progenitors/ cell activity in bone marrow as determined by flow cytometry and by karyotype analysis of progenitor-derived erythroid (erythroid burstforming unit [BFU-E]), myeloid (CFU-GM), and mixed (CFU-Mix) hematopoietic colonies (Table I).

Bone marrow cells were obtained from the posterior iliac crest under general anesthesia and the BMNC were isolated by separation on
Ficoll-Hypaque $(27,28)$. Flow cytometric analysis of pooled samples from each animal revealed the presence of human $\mathrm{CD} 45^{+}$cells in all three marrow preparations ( Table II). The number of BMNC obtained from each donor and the numbers of $\mathrm{CD}_{4} 5^{+}$cells isolated by panning are also shown in Table II. Human $\mathrm{CD}^{+} 5^{+}$cells were isolated by positive selection using goat anti-mouse T-25 cell culture flasks (MicroCellector; Applied Immune Sciences, Menlopark, CA) and the procedure recommended by the manufacturer. The isolated $\mathrm{CD}^{2} 5^{+}$cells from all three donors were pooled and resuspended in Iscove's modified Dulbecco's medium containing $10 \%$ FCS and $5 \mathrm{ng} / \mathrm{ml}$ each of recombinant human IL-3 and GM-CSF. The mixture was incubated at $37^{\circ} \mathrm{C}$, $5 \% \mathrm{CO}_{2}$ in humidified air for $16 \mathrm{~h}$. We have shown previously that short-term exposure to these growth factors results in improved donor cell engraftment in this model $(29,30)$. Immediately before transplantation into preimmune fetal sheep recipients, the cells were pelleted by centrifugation, resuspended in the same medium, and divided into six equal aliquots. The amniotic bubble procedure was used for in utero transplantation as described in detail previously (31). Each of the six 50-54-d-old fetal sheep was injected with one aliquot of cells in $0.5 \mathrm{ml}$ vol. The recipients were allowed to complete gestation and were examined for donor cell engraftment beginning at $3 \mathrm{wk}$ after birth.

Monitoring of engraftment. Peripheral blood cells and BMNC were analyzed for the presence of donor (human ) cells by flow cytometry on a FACScan ${ }^{\star}$ flow cytometer as described (27). The samples were also examined for the presence of donor cells by karyotyping of cells (after PHA stimulation ) and of progenitor-derived hematopoietic colonies as detailed previously $(27,32)$. BMNC $\left(0.4-2 \times 10^{5}\right.$ cells $\left./ \mathrm{ml}\right)$ were cultured in methylcellulose as described $(27,32)$. All cultures were established with Iscove's modified Dulbecco's medium and erythropoietin (2 IU/ml). For optimal growth of sheep CFU-Mix, CFU-GM, and BFU-E, the cultures were supplemented $(5 \% \mathrm{vol} / \mathrm{vol})$ with a preparation of PHA-stimulated leukocyte-conditioned medium produced from a mixture of fetal sheep spleen, thymus, liver, and bone marrow cells in Iscove's modified Dulbecco's medium with $2 \%$ fetal sheep serum $(27,32)$. In these cultures maximal numbers of sheep colonies develop by day 9 of incubation. Optimal growth of human hematopoietic progenitors was achieved with the addition of $5 \mathrm{ng} / \mathrm{ml}$ each of human IL-3 and GM-CSF to cultures of cells from the same preparations of BMNC in the absence of sheep PHA-stimulated leukocyteconditioned medium. Colonies were enumerated by type, removed from the plates individually, and processed for karyotyping on days 9 (sheep) and 19 (human) of incubation $\left(37^{\circ} \mathrm{C}, 5 \% \mathrm{Co}^{2}\right.$ humidified air) as described (27).

\section{Results}

Table II summarizes the numbers of BMNC obtained from each donor and the percentage of $\mathrm{CD}_{4}{ }^{+}$cells in each preparation. It can be seen that, although on the average $3.3 \%$ of $\mathrm{BMNC}$ were $\mathrm{CD}_{45}{ }^{+}$( representing $\sim 6.3 \times 10^{7}$ cells), we were able to recover only $46 \%$ of these cells or $\sim 2.9 \times 10^{7}$ cells by panning. Therefore, each preimmune fetus was transplanted with $\sim 4.9 \times 10^{6}$ donor $\mathrm{CD}_{4} 5^{+}$cells (equivalent to $4.9 \times 10^{8}$

Table II. Summary of Donor Cell Preparations

\begin{tabular}{|c|c|c|c|c|}
\hline & \multicolumn{4}{|c|}{ Donor lambs } \\
\hline & 3419 & 3425 & $3425 \mathrm{C}$ & Total \\
\hline Number of BMNC obtained & $6.3 \times 10^{8}$ & $7.1 \times 10^{8}$ & $5.7 \times 10^{8}$ & $1.9 \times 10^{9}$ \\
\hline Number of $\mathrm{CD} 45^{+}$cells & $24.6 \times 10^{6}$ & $22.7 \times 10^{6}$ & $16.0 \times 10^{6}$ & $6.3 \times 10^{7}$ \\
\hline (percentage of total) & 3.9 & 3.2 & 2.8 & 3.3 \\
\hline Number of $\mathrm{CD} 45^{+}$cells obtained by panning & $11.3 \times 10^{6}$ & $11.4 \times 10^{6}$ & $6.5 \times 10^{6}$ & $2.9 \times 10^{7}$ \\
\hline (percentage of total) & 1.8 & 1.5 & 1.1 & 1.5 \\
\hline
\end{tabular}


Table III. Relative Distribution of Donor (Human) Progenitors in Marrow of Newborn Lambs

\begin{tabular}{|c|c|c|c|c|c|c|c|c|c|}
\hline \multirow[b]{3}{*}{ Animal } & \multicolumn{9}{|c|}{ Colonies with human karyotype* } \\
\hline & \multicolumn{3}{|c|}{ CFU-Mix } & \multicolumn{3}{|c|}{ CFU-GM } & \multicolumn{3}{|c|}{ BFU-E } \\
\hline & 3 wk & $24 \mathbf{w k}$ & $46 \mathrm{wk}$ & $3 \mathbf{w k}$ & 24 wk & $46 \mathrm{wk}$ & $3 \mathbf{w k}$ & $24 \mathrm{wk}$ & $46 \mathrm{wk}$ \\
\hline & \multicolumn{3}{|c|}{$\%$} & \multicolumn{3}{|c|}{$\%$} & \multicolumn{3}{|c|}{$\%$} \\
\hline G-27 & 2.1 & 3.8 & 2.9 & 5.8 & 8.2 & 7.6 & 0 & 4.0 & 0 \\
\hline G-28 & 3.8 & 4.0 & 3.2 & 12.2 & 14.8 & 6.8 & 3.9 & 9.2 & 0 \\
\hline
\end{tabular}

* The values represent the percentage of total numbers of colonies enumerated. Bone marrow cells were cultured in multiple methylcellulose plates as described (27). Total colony numbers were determined on days 9 (mostly sheep) and 19 (primarily human) of incubation; all three progenitor types (CFU-Mix, CFU-GM, and BFU-E) were detected on both days. On day 19, colonies were removed from the plate and individually processed for karyotyping (27). For each point $21-46$ colonies were analyzed.

cells/ $\mathrm{kg}$ estimated fetal body wt); all fetuses survived to term and were born alive. All six newborn lambs were evaluated for the presence of human cells at 3 wk after birth. Two sheep exhibited human cell chimerism. This was evident from the presence of significant numbers of progenitors capable of giving rise to colonies with human karyotype (Table III) and of cells expressing CD45 antigen (Table IV) in blood and marrow of these two lambs. Table III also shows the relative distribution of donor (human) erythroid (BFU-E), myeloid (CFUGM), and multipotent (CFU-Mix) progenitors in bone marrow of these sheep at 24 and 46 wk after birth. Except for BFU-E, which were not detected at $46 \mathrm{wk}$, bone marrow from these lambs continued to express human CFU-Mix and CFUGM since birth. The persistence of donor cell engraftment and expression is also demonstrated by results presented in Table IV, which shows the presence of $\mathrm{CD} 45^{+}$cells in blood and marrow of the two chimeric sheep until 68 wk after birth (the last testing period). The results presented in Table $\mathrm{V}$ show the phenotype of human cell subpopulations present in bone marrow of lambs G-27 and G-28 at 6 mo of age (i.e., 9 mo after transplantation ). In addition to $\mathrm{CD} 45^{+}$cells, marrow of both sheep contained small but detectable numbers of $\mathrm{CD} 45^{+}$cells that expressed CD34, CD3, or CD14 antigens. No CD22 ${ }^{+}$cells were detected in marrow of lamb G-27, while animal G-28 exhibited $0.5 \% \mathrm{CD} 22^{+}$cells (Table V).

\section{Discussion}

The results presented here provide strong evidence that the expression of donor (human) hematopoietic cells in the hu-

Table IV. Relative Distribution of Donor (Human) Cells in Newborn Lambs

\begin{tabular}{llcccc}
\hline & & \multicolumn{4}{c}{ CD45 $^{+}$cells* } \\
\cline { 3 - 6 } Animal & Tissue & $3 \mathrm{wk}$ & $24 \mathrm{wk}$ & $46 \mathrm{wk}$ & $68 \mathrm{wk}$ \\
\hline \multirow{3}{*}{ G-27 } & & $\%$ & $\%$ & $\%$ & $\%$ \\
& Blood & 0.8 & 3.2 & $<0.5$ & 1.7 \\
G-28 & Marrow & 2.9 & 8.8 & 4.6 & 6.3 \\
& Blood & $<0.5$ & 1.6 & 1.1 & 0.8 \\
& Marrow & 3.7 & 5.7 & 6.2 & 7.9
\end{tabular}

* Values represent the frequency of human cells detected flow cytometrically after labeling with antibody-recognizing CD45 antigen. man/sheep chimeric animals is associated with the engraftment and possibly with expansion and self-renewal of the longterm repopulating human HSC. Engraftment of human HSC in this xenograft setting occurs because the unique aspects of fetal development create a permissive environment for the engraftment and tolerance of immunologically foreign HSC (3336). Among these, the preimmune status of the early gestational age fetus (37-39) and the availability of sites within the developing hematopoietic tissues of the young fetus (33) play critical roles in facilitating the acceptance and engraftment of the donor human HSC. We have shown that in the sheep the majority of normal donor HSC engraft within the fetal bone marrow (33) and that for most of the prenatal period the bone marrow does not participate in the formation of mature blood cells (33), presumably, because the need of the fetus for blood cells is satisfied by the liver. It is possible that this absence of a significant demand for differentiated cellular elements allows bone marrow stem cells time to establish/expand themselves. The system may also benefit from the possible processing of cells by the fetal thymic microenvironment, which could theoretically result in long-term cellular and humoral tolerance (40). It is of interest to note that the engraftment of human

Table V. Phenotypical Analysis of Chimeric Sheep G-27 and G-28 at $6 \mathrm{Mo}$ of Age

\begin{tabular}{llc}
\hline & \multicolumn{2}{c}{ Human cell frequency* } \\
\cline { 2 - 3 } & G-27 & G-28 \\
\hline & $\%$ & $\%$ \\
$\mathrm{CD}^{*} 5^{+}$ & 8.8 & 5.7 \\
$\mathrm{CD} 34^{+}$ & 0.4 & 0.3 \\
$\mathrm{CD}^{+}$ & 1.6 & 1.0 \\
$\mathrm{CD} 22^{+}$ & $0^{\ddagger}$ & 0.5 \\
$\mathrm{CD14}$ & 0.8 & 0.4 \\
\hline
\end{tabular}

* Values represent the frequency of human cells present in BMNC detected flow cytometrically after labeling with antibodies recognizing the different $C D$ antigens. We are unable to explain why the majority of $\mathrm{CD}^{+} 5^{+}$cells in these preparations did not exhibit lineage-specific markers. It is possible that, as happens occasionally with human/ sheep chimeric bone marrow cells, the light density layer included significant numbers of mature white blood cells which are CD45 ${ }^{+}$ but were not phenotyped. ${ }^{\ddagger}$ On other occasions bone marrow cells from lamb G-27 expressed CD22. 
HSC in this model has been accompanied by multilineage expression involving donor cells of erythroid, myeloid, and lymphoid origins $(27,28)$. The lymphoid expression has included both $\mathrm{T}$ and $\mathrm{B}$ lymphocytes $(27,28)$.

Considerable experimental evidence in animals now indicates the existence of different pools of HSC involved in the repopulation of hematopoietic tissues after extensive depletion of an animal's own HSC pool. The prototype for these pools can be seen in days 8 and 12-14 spleen colony-forming cells in mice (12-15). When lethally irradiated mice are infused with an extrinsic source of HSC, the first set of spleen colonies occur in the recipient mouse after $8 \mathrm{~d}$. However, while this pool of cells can repopulate the animal's system, it is short lived. The longer-term repopulation of the hematopoietic tissues in these recipients results from the engraftment and proliferative activity of a more primitive pool of HSC that form spleen colonies between days 12 and 14 . Operationally, these two pools can be distinguished by the fact that the long-lived HSC, recovered from the primary recipients and transplanted into secondary irradiated recipients, can repopulate the hematopoietic system in the latter group. This is possible because of the self-renewing activity of the HSC which also prevents its depletion (12-15).

Analyses of the proliferative potentials of different populations of human hematopoietic cells expressing the CD34 antigen helped identify at least two distinct subsets of human pluripotent HSC capable of extensive proliferation in vitro $(17,21-$ 24 ). The more primitive subset was found to give rise to both hematopoietic precursors and stromal cells in vitro (41). The human/sheep xenograft model is ideally suited to study the in vivo repopulating and self-renewal potential of these human HSC subsets. The rarity of the primitive HSC in human hematopoietic tissue frequently results in the isolation of relatively small numbers of highly characterized HSC subsets (42), which while adequate for in vitro studies may not be sufficient for the evaluation of their in vivo potential. The relatively small size of the preimmune sheep fetus $(\approx 10 \mathrm{~g}$ at the time of transplantation ) and the availability of sites within the marrow ontogenetically primed to accept migrating HSC (including donor HSC) permit the assessment of the engraftment and proliferation potential of the relatively small cell inoculum. In this regard, we have shown that the transplantation of as few as 4 $\times 10^{4}$ highly purified adult human $\mathrm{CD}^{3} 4^{+} \mathrm{HLA}^{-D R^{-}}$bone marrow cells into these young fetuses resulted in the engraftment and long-term multilineage expression and expansion of donor HSC (28). The long-term assessment of donor HSC function is possible because the large size of chimeric sheep allows sampling of bone marrow and blood at desired intervals (e.g., 3-4 wk) for long periods without significantly affecting the hematopoietic status of the lamb. Such long-term evaluation can help distinguish between the proliferative activities of the most primitive human HSC and transient engraftment resulting from the more committed hematopoietic progenitors.

\section{Acknowledgments}

This work was supported by National Institutes of Health grants HL46556, HL-48378, and HL-40722, by the Department of Veterans Affairs, and by the G. Harold and Leila Y. Mathers Charitable Foundation.

\section{References}

1. Till, J. E., and E. A. McCulloch. 1961. A direct measurement of the radiation sensitivity of normal mouse bone marrow cells. Radiat. Res. 14:213-222.
2. Abramson, S., R. G. Miller, and R. A. Phillips. 1977. The identification in adult bone marrow of pluripotent and restricted stem cells of the myeloid and lymphoid systems. J. Exp. Med. 145:1567-1579.

3. Wu, A. M., J. E. Till, L. Siminovitch, and E. A. McCulloch. 1968. Cytological evidence for a relationship between normal hematopoietic colony-forming cells and cells of the lymphoid system. J. Exp. Med. 127:455-464.

4. Lemischka, I. R., D. H. Ramlet, and R. C. Mulligan. 1986. Developmental potential and dynamic behavior of hematopoietic stem cells. Cell. 45:917-927.

5. Visser, J. W. M., J. G. J. Bauman, A. H. Mulder, J. F. Eliason, and A. M. de Leeuw. 1984. Isolation of murine pluripotent hemopoietic stem cells. $J$. Exp. Med. 159:1576-1590.

6. Tavassoli, M. 1989. Bone marrow and hemopoiesis. In Aplastic Anemia and Other Bone Marrow Failure Syndromes. N. T. Shahidi, editor. Springer-Verlag New York Inc., New York. 1-24.

7. Brecher, G., S. Nelsen, M. Yee, J. Bull, and E. P. Cronkite. 1988. Pluripotent stem cells with normal or reduced self renewal survive lethal irradiation. Exp. Hematol. (NY). 16:627-630.

8. Verfaillie, C., K. Blakolmer, and P. McGlave. 1990. Purified primitive human hematopoietic progenitor cells with long-term in vitro repopulating capacity adhere selectively to irradiated bone marrow stroma. J. Exp. Med. 172:509520.

9. Srour, E. F., J. E. Brandt, R. A. Briddell, T. Leemhuis, K. van Besien, and R. Hoffman. 1991. Human CD34 ${ }^{+}$HLA-DR- bone marrow cells contain progenitor cells capable of self-renewal, multilineage differentiation, and long-term in vitro hematopoiesis. Blood Cells (NY). 17:287-295.

10. McCune, J. M., R. Namikawa, H. Kaneshima, L. D. Shultz, M. Leiberman, and I. L. Weissman. 1988. The SCID-hu mouse: murine model for the analysis of human hematolymphoid differentiation and function. Science (Wash. DC). 241:1632-1639.

11. Spangrude, G. J., S. Heimfeld, and I. L. Weissman. 1989. Purification and characterization of mouse hematopoietic stem cells. Science (Wash. DC). 241:58-62.

12. Magli, M. C., N. N. Iscove, and N. Odartchenko. 1982. Transient nature of early hemopoietic spleen colonies. Nature (Lond.). 295:527-529.

13. Schofield, R., T. M. Dexter, B. I. Lord, and N. G. Testa. 1986. Comparison of hemopoiesis in young and old mice. Mech. Ageing Dev. 34:1-12.

14. Boggs, D. R., S. S. Boggs, D. F. Saxe, L. A. Gress, and D. R. Canfield. 1982. Hematopoietic stem cells with high proliferation potential. Assay of their concentration in marrow by the frequency and duration of cure of $\mathrm{W} / \mathrm{W}^{\mathrm{v}}$ mice. J. Clin. Invest. 70:242-253.

15. Leary, A. G., M. Ogawa, L. C. Strauss, and C. I. Civin. 1984. Single cell origin of multilineage colonies in culture. Evidence that differentiation of multipotent progenitors and restriction of proliferative potential of monopotent progenitors are stochastic processes. J. Clin. Invest. 74:2193-2197.

16. Sutherland, H. J., C. J. Eaves, P. M. Lansdorp, J. D. Thacker, and D. E. Hogge. 1991. Differential regulation of primitive human hematopoietic cells in long-term cultures maintained on genetically engineered murine stromal cells. Blood. 78:666-672.

17. Verfaillie, C. M. 1992. Direct contact between human primitive hematopoietic progenitors and bone marrow stroma is not required for long-term in vitro hematopoiesis. Blood. 79:2821-2826.

18. Kamel-Reid, S., and J. E. Dick. 1988. Engraftment of immune-deficient mice with human hematopoietic stem cells. Science (Wash. DC). 242:17061709.

19. Civin, C. I., M. L. Banquerigo, L. C. Strauss, and M. R. Loken. 1987. Antigenic analysis of hematopoiesis. VI. Flow cytometric characterization of MY-10-positive progenitor cells in normal human bone marrow. Exp. Hematol. (NY). 15:10-17.

20. Bertoncello, I., T. R. Bradley, G. S. Hodgson, and J. M. Dunlop. 1991. The resolution, enrichment, and organization of normal bone marrow high proliferative potential colony-forming cell subsets on the basis of rhodamine-123 fluorescence. Exp. Hematol. (NY). 19:174-178.

21. Leary, A. G., and M. Ogawa. 1987. Blast cell colony assay for umbilical cord blood and adult bone marrow progenitors. Blood. 69:953-956.

22. Srour, E. F., J. E. Brandt, R. A. Briddell, S. Grigsby, T. Leemhuis, and R. Hoffman. 1993. Long-term generation and expansion of human primitive hematopoietic progenitor cells in vitro. Blood. 81:661-669.

23. Sutherland, H. J., D. E. Hogge, D. Cook, and C. J. Eaves. 1993. Alternative mechanisms with and without steel factor support primitive human hematopoiesis. Blood. 81:1465-1470.

24. Miller, J. S., C. Verfaillie, and P. McGlave. 1992. The generation of human natural killer cells from $\mathrm{CD} 34^{+} / \mathrm{DR}^{-}$primitive progenitors in long-term marrow culture. Blood. 80:2182-2187.

25. Dick, J. E. 1989. Establishment of assays for human hematopoietic cells in immune deficient mice. Curr. Top. Microbiol. Immunol. 152:219-224.

26. Barry, T. S., D. M. Jones, C. B. Richter, and B. F. Haynes. 1991. Successful engraftment of human postnatal thymus in severe combined immune deficient (SCID) mice. Differential engraftment of thymic components with irradiation versus anti-asialo GM-01 immunosuppressive regimens. J. Exp. Med. 173:167-180. 
27. Zanjani, E. D., M. G. Pallavicini, J. L. Ascensao, A. W. Flake, R. G. Langlois, M. Reitsma, F. R. MacKintosh, D. Stutes, M. R. Harrison, and M. Tavassoli. 1992. Engraftment and long-term expression of human fetal hemopoietic stem cells in sheep following transplantation in utero. J. Clin. Invest. 89:1178-1188.

28. Srour, E. F., E. D. Zanjani, J. E. Brandt, T. Leemhuis, R. A. Briddell, N. A. Heerema, and R. Hoffman. 1992. Sustained human hematopoiesis in sheep transplanted in utero during early gestation with fractionated adult human bone marrow cell. Blood. 79:1404-1412.

29. Tavassoli, M., M. Konno, E. Shiota, J. Omoto, J. Minguell, and E. D. Zanjani. 1991. Enhancement of grafting efficiency of the transplanted marrow cells by preincubation with IL-3 and GM-CSF. Blood. 77:1599-1606.

30. Zanjani, E. D., J. A. Ascensao, M. R. Harrison, and M. Tavassoli. 1992. Ex vivo incubation with growth factors enhances engraftment of fetal hemopoietic cells transplanted in sheep fetuses. Blood. 79:3045-3049.

31. Flake, A. W., M. R. Harrison, N. S. Adzick, and E. D. Zanjani. 1986. Transplantation of fetal hematopoietic stem cells in utero: the creation of hematopoietic chimeras. Science (Wash. DC). 233:776-778.

32. Zanjani, E. D., R. F. MacKintosh, and M. R. Harrison. 1991. Hematopoietic chimerism in sheep and non human primates by in utero transplantation of fetal hematopoietic stem cells. Blood Cells (NY). 17:349-363.

33. Zanjani, E. D., J. L. Ascensao, and M. Tavassoli. 1993. Liver-derived hematopoietic stem cells selectively and preferentially home to the fetal bone marrow. Blood. 81:399-404.
34. Billingham, R., L. Brent, and P. B. Medawar. 1953. Actively acquired tolerance of foreign cells. Nature (Lond.). 172:603-607.

35. Binns, R. 1969. Bone marrow and lymphoid cell injection of the pig fetus resulting in transplantation tolerance or immunity, and immunoglobin production. Nature (Lond.). 214:179-181.

36. Barnes, R. D., B. E. Pottinger, J. Marston, P. Flecknell, and R. H. Ward. 1983. Immunological tolerance induced by in utero injection. J. Med. Genet. 20:41-45.

37. Owen, J. J. T., and E. J. Jenkinson. 1981. Embryology of the immune system. Prog. Allergy. 29:1-34.

38. Kyewski, B. A. 1987. Seeding of thymic microenvironments defined by distinct thymocyte-stromal cell interactions is developmentally controlled. $J$. Exp. Med. 166:520-538.

39. Jotereau, F., F. Heuze, V. Salomon-Vie, and H. Gascan. 1987. Cell kinetics in the fetal mouse thymus: precursors cell input, proliferation, and emigration. J. Immunol. 138:1026-1030.

40. Palmiter, R., L. Burkly, and R. H. Flavell. 1988. The effect of thymus environment on T cell development and tolerance. Cell. 53:627-634.

41. Huang, S., and W. M. M. Terstappen. 1992. Formation of haematopoietic microenvironment and haematpoietic stem cells from a single human bone marrow cell. Nature (Lond.). 360:745-749.

42. Srour, E. F., R. Hoffman, and E. D. Zanjani. 1992. Animal models for human hematopoiesis. J. Hematotherapy. 1:143-153. 